\title{
Prowadzenie oceny stanu środowiska glebowego pod kątem występowania zanieczyszczeń węglowodorami w aspekcie obowiązujących uregulowań prawnych
}

\begin{abstract}
W artykule opisano obowiązujące regulacje prawne w zakresie oznaczania zawartości węglowodorów w próbkach gleby. Zebrano i przedstawiono dopuszczalne graniczne wartości stężeń węglowodorów w glebie, jak również metodyki referencyjne zalecane w pomiarach i badaniach zanieczyszczeń węglowodorowych w tym elemencie środowiska. Przeprowadzony przegląd dopuszczalnych granicznych zawartości węglowodorów w glebie dowiódł, że wartości dozwolonych stężeń węglowodorów są zróżnicowane w szerokim zakresie, w zależności od rodzaju oznaczanej substancji. Przegląd regulacji prawnych ukazał także, że podstawową metodyką referencyjną jest chromatografia gazowa (GC) w zakresie oznaczania węglowodorów alifatycznych oraz wysokosprawna chromatografia cieczowa (HPLC) do oznaczania wielopierścieniowych węglowodorów aromatycznych (WWA).
\end{abstract}

Słowa kluczowe: zanieczyszczenia węglowodorowe, gleba, regulacje prawne.

\section{Conducting assessment of the soil environment for pollution by hydrocarbons in terms of the applicable regulations}

The article describes the current legislation regarding the determination of hydrocarbons concentration in soil samples. In the paper the permitted limits of hydrocarbons concentration in the soil was collected and presented, as well as methods recommended for the reference measurement and testing of hydrocarbon contamination in the environmental medium. A survey of acceptable limits of hydrocarbons concentration in soil, showed that the limit of concentrations of hydrocarbons vary widely, depending on the type of determined substance. Review of legal regulations also showed, that the primary reference methodology, is gas chromatography (GC) for the determination of aliphatic hydrocarbons, and high performance liquid chromatography (HPLC) for the determination of polycyclic aromatic hydrocarbons (PAHs).

Key words: hydrocarbon contamination, soil, legal regulations.

\section{Wstęp}

W związku ze wzrostem świadomości społeczeństwa, jak również bardzo szybko postępującym rozwojem wiedzy i techniki, tworzone są lub podlegają weryfikacji akty prawne regulujące konieczność oznaczania substancji szkodliwych w poszczególnych elementach środowiska, generowanych odpadach czy produktach. Dokumenty te wprowadzają coraz bardziej restrykcyjne wymagania dotyczące jakości środowiska przyrodniczego.

Wśród substancji szkodliwych, toksycznych, mających negatywny wpływ na środowisko oraz zdrowie i życie ludzi niewątpliwie wymienić należy szeroką grupę związków orga- nicznych, czyli węglowodory. Oznaczanie zawartości węglowodorów w wodach, glebach, powietrzu oraz odpadach jest istotnym punktem prowadzenia oceny stanu zanieczyszczenia danego elementu środowiska. Działania tego typu świadczą o dbałości o stan środowiska podmiotu będącego właścicielem danego terenu. Konieczność oznaczania zawartości węglowodorów w próbkach wód, gleb i odpadów wynika: po pierwsze $-\mathrm{z}$ ich szkodliwych właściwości, a po drugie $\mathrm{z}$ faktu, że substancje te mogą powodować długo utrzymujące się niekorzystne zmiany. W związku z tym dopuszczalne graniczne wartości dla poszczególnych węglowodorów 
lub też ich sumarycznej zawartości są regulowane licznymi przepisami prawa, limitującymi zawartość tych zanieczyszczeń w poszczególnych elementach środowiska, produktach czy odpadach. Regulacje prawne wskazują również niejednokrotnie referencyjne metodyki badawcze, służące do oceny zawartości węglowodorów w badanych próbkach, lub też pokazują możliwość zastosowania metod im równoważnych (pod względem specyficzności i czułości) [1,2].

$\mathrm{W}$ artykule omówiono obowiązujące regulacje prawne dotyczące oceny jakości środowiska glebowego, ze szczególnym zwróceniem uwagi na wymagania odnoszące się do oznaczania zawartości węglowodorów w glebach.

\section{Analiza regulacji prawnych dotyczących oznaczania zawartości węglowodorów w środowisku glebowym}

Do dnia 5 września 2016 roku do oceny stanu środowiska glebowego miało zastosowanie Rozporzadzenie Ministra Środowiska z dnia 9 września 2002 r. w sprawie standardów jakości gleby i standardów jakości ziemi (Dz. U. z 2002 r. nr 165, poz. 1359) [5]. Dokument ten określał sześć grup zanieczyszczeń:

- metale (As - arsen, Ba - bar, Cr - chrom, $\mathrm{Sn}$ - cyna, $\mathrm{Zn}$ - cynk, Cd - kadm, Co - kobalt, $\mathrm{Cu}$ - miedź, Mo - molibden, $\mathrm{Ni}$ - nikiel, $\mathrm{Pb}$ - ołów, $\mathrm{Hg}$ - rtęć),

- zanieczyszczenia nieorganiczne (cyjanki wolne, cyjanki - związki kompleksowe),

- węglowodory (benzyna suma - węglowodory $\mathrm{C}_{6}-\mathrm{C}_{12}$; olej mineralny - węglowodory $\mathrm{C}_{12}-\mathrm{C}_{35}$; ;ęglowodory aromatyczne - benzen, etylobenzen, toluen, ksylen, styren, suma BTEX; wielopierścieniowe węglowodory aromatyczne - naftalen, fenantren, antracen, fluoranten, chryzen, benzo(a)antrancen, benzo(a)piren, benzo(k)fluaranten, benzo(ghi)perylen oraz suma WWA),

- węglowodory chlorowane,

- środki ochrony roślin (pestycydy chloroorganiczne, pestycydy - związki niechlorowane),

- zanieczyszczenia organiczne zaliczane do różnych typów związków (tetrahydrofuran, pirydyna, tetrahydrotiofen, cykloheksan, fenol, krezole i ftalany).

Rozporządzenie specyfikowało trzyetapowy sposób postępowania, mający na celu sprawdzenie, czy określone dopuszczalne wartości stężeń poszczególnych zanieczyszczeń w glebie nie zostały przekroczone. W tym celu w etapie pierwszym ustalana była lista substancji, których wystąpienia można się spodziewać ze względu na rodzaj prowadzonej działalności. W etapie drugim wykonano pomiary wstępne mające na celu stwierdzenie, czy wytypowane w etapie pierwszym zanieczyszczenia rzeczywiście występują. Natomiast w etapie trzecim, jeśli obecność zanieczyszczeń została potwierdzona, przeprowadzano badania szczegółowe, które pozwały określić dokładne stężenia zanieczyszczeń oraz były podstawą do ustalenia zakresu i wybrania sposobu przeprowadzenia rekultywacji gleby/gruntu.

Dopuszczalne stężenia zanieczyszczeń w glebie (standardy jakości) były zróżnicowane w zależności od funkcji, jaką pełniły grunty, a więc były różne dla:
- gruntów poddanych ochronie na podstawie przepisów ustawy Prawo wodne i przepisów o ochronie przyrody (grupa A),

- użytków rolnych, gruntów leśnych, gruntów zadrzewionych i zakrzewionych, gruntów zabudowanych i zurbanizowanych (z wyłączeniem gruntów pod stawami, pod rowami, terenów przemysłowych, użytków kopalnych i terenów komunikacyjnych) (grupa B),

- terenów przemysłowych, użytków kopalnych i terenów komunikacyjnych (grupa C).

W grupie terenów przemysłowych dalsze zróżnicowanie dopuszczalnych wartości stężeń zanieczyszczeń w glebie lub ziemi było związane z głębokością $(0 \div 2 \mathrm{~m}$ ppt i $2 \div 15 \mathrm{~m} \mathrm{ppt})$ oraz z wodoprzepuszczalnością w interwale $2 \div 15 \mathrm{~m} \mathrm{ppt}$ (do $10^{-7} \mathrm{~m} / \mathrm{s}$ i poniżej $10^{-7} \mathrm{~m} / \mathrm{s}$ ).

Rozporządzenie [5], jak już wspomniano, zostało jednak uchylone z dniem 5 września 2016 r. Przyczyniło się do tego wprowadzenie Rozporzadzenia Ministra Środowiska z dnia 1 września $2016 r$. w sprawie sposobu prowadzenia oceny zanieczyszczenia powierzchni ziemi (Dz. U. z 2016 r. nr 0, poz. 1395) [4].

Wprowadzenie rozporządzenia [4] jest wynikiem prac nad implementacją do prawa polskiego przepisów dyrektywy IED, tj. Dyrektywy Parlamentu Europejskiego i Rady 2010/75/UE z dnia 24 listopada 2010 r. w sprawie emisji przemystowych (zintegrowane zapobieganie zanieczyszczeniom i ich kontrola) (Dz. U. UE L 334 z 17 grudnia 2010 r., z późn. zm.) [3]. Regulacja dotycząca ochrony powierzchni ziemi zawarta w dyrektywie IED ma charakter szczątkowy i została ujęta w art. 3 pkt 18, 19, 21; art. 12 ust. 1 lit. e); art. 14 ust. 1 lit. e) oraz art. 22 dyrektywy. Art. 22 dokumentu [3] stanowi, że w przypadku, gdy działalność obejmuje wykorzystywanie, produkcję lub uwalnianie substancji stwarzających zagrożenie, mając na uwadze możliwość skażenia gleby i wód podziemnych na terenie instalacji, operator przygotowuje i przedkłada właściwemu organowi sprawozdanie bazowe przed rozpoczęciem eksploatacji instalacji lub przed uaktualnieniem pozwolenia na eksploatację instalacji. Sprawozdanie bazowe zawiera informacje niezbędne do ustalenia stanu zanieczyszczenia gleby i wód podziemnych w taki sposób, aby możliwe było wykonanie ilościowego 
porównania ze stanem po zakończeniu prac. Zgodnie z pkt. 3 po zakończeniu działalności operator dokonuje oceny stanu zanieczyszczenia gleby i wód podziemnych substancjami stwarzającymi zagrożenie - stosowanymi, produkowanymi lub uwalnianymi przez instalację. W przypadku, gdy instalacja spowodowała znaczące zanieczyszczenie gleby lub wód podziemnych określonymi niebezpiecznymi substancjami (w porównaniu ze stanem określonym w sprawozdaniu bazowym), operator podejmuje niezbędne środki mające na celu przeciwdziałanie temu zanieczyszczeniu, aby przywrócić teren do stanu wyjściowego. Natomiast w przypadku, gdy od operatora nie wymaga się przygotowania sprawozdania bazowego (art. 22 pkt 4), po zakończeniu działalności podejmuje on niezbędne czynności mające na celu usunięcie, kontrolę, ograniczenie rozprzestrzeniania się lub zmniejszenie ilości niebezpiecznych substancji. Ważne jest to, aby teren, uwzględniając jego aktualny i zatwierdzony przyszły kierunek użytkowania, przestał stanowić znaczące zagrożenie dla zdrowia ludzi lub dla środowiska w związku z zanieczyszczeniem gleby i wód podziemnych na skutek dozwolonej działalności i z uwzględnieniem stanu terenu, na którym położona jest instalacja.

Rozporządzenie [4] określa sposób prowadzenia oceny zanieczyszczenia powierzchni ziemi, w tym:

- substancje powodujące ryzyko szczególnie istotne dla ochrony powierzchni ziemi, ich dopuszczalne zawartości w glebie i w ziemi, zróżnicowane dla poszczególnych właściwości gleby oraz grup gruntów, wydzielonych w oparciu o sposób ich użytkowania,

- szczegółowe wymagania dotyczące ustalania dopuszczalnej zawartości w glebie oraz w ziemi substancji powodującej ryzyko, innej niż wskazana powyżej, z uwzględnieniem analizy jej wpływu na zdrowie ludzi i stan środowiska,

- etapy identyfikacji terenów zanieczyszczonych (w szczególności sposób ustalenia działalności mogącej być przyczyną zanieczyszczenia na danym terenie obecnie lub w przeszłości; metoda określenia listy substancji powodujących ryzyko, których wystąpienie w glebie lub ziemi jest spodziewane ze względu na działalność mogącą być przyczyną zanieczyszczenia; źródła informacji istotne dla oceny zagrożenia zanieczyszczeniem gleby lub ziemi; warunki uznawania istniejących badań zanieczyszczenia gleby i ziemi za aktualne oraz etapy i sposób prowadzenia badań zanieczyszczenia gleby i ziemi),

- rodzaje działalności mogących z dużym prawdopodobieństwem powodować historyczne zanieczyszczenie powierzchni ziemi, wraz ze wskazaniem przykładowych dla tych działalności zanieczyszczeń,

- referencyjne metodyki wykonywania badań zanieczyszczenia gleby i ziemi,
- szczegółowe wymagania dotyczące oceny zanieczyszczenia gleby, ziemi lub wód gruntowych na terenie zakładu, gdzie jest lub była w przeszłości eksploatowana instalacja wymagająca uzyskania pozwolenia zintegrowanego, w celu zapewnienia identyfikacji każdego zanieczyszczenia przed uruchomieniem instalacji, w trakcie jej eksploatacji oraz po zamknięciu.

Substancje powodujące ryzyko szczególnie istotne dla ochrony powierzchni ziemi, ich dopuszczalne zawartości w glebie oraz w ziemi, zróżnicowane dla poszczególnych właściwości gleby oraz grup gruntów wydzielonych w oparciu o sposób ich użytkowania, określa załącznik nr 1 do rozporządzenia [4]. Wśród wymienionych w tym dokumencie zanieczyszczeń znajdują się:

- metale i metaloidy (As - arsen, $\mathrm{Ba}$ - bar, $\mathrm{Cr}$ - chrom, $\mathrm{Sn}$ - cyna, Zn - cynk, Cd - kadm, Co - kobalt, $\mathrm{Cu}$ - miedź, Mo - molibden, Ni - nikiel, $\mathrm{Pb}$ - ołów, $\mathrm{Hg}$ - rtęć),

- zanieczyszczenia nieorganiczne (cyjanki wolne, cyjanki - związki kompleksowe),

- węglowodory (benzyny i oleje - suma węglowodorów $\mathrm{C}_{6}-\mathrm{C}_{12}$ oraz suma węglowodorów $\mathrm{C}_{12}-\mathrm{C}_{35}$; węglowodory aromatyczne - benzen, etylobenzen, toluen, ksyleny, styren; wielopierścieniowe węglowodory aromatyczne - naftalen, antracen, chryzen, benzo(a)antrancen, dibenzo(a,h) antracen, benzo(a)piren, benzo(b)fluaranten, benzo(k)fluaranten, benzo(ghi)perylen oraz indeno(1,2,3-c,d)piren),

- węglowodory chlorowane,

- środki ochrony roślin (pestycydy chloroorganiczne, pestycydy - związki niechlorowe),

- pozostałe zanieczyszczenia (tetrahydrofuran, pirydyna, tetrahydrotiofen, cykloheksan, fenol, krezole i ftalany).

Dopuszczalne zawartości wymienionych powyżej zanieczyszczeń określa się dla grup gruntów wydzielonych w oparciu o sposób ich użytkowania, z wyłączeniem gruntów pod wodami, ale uwzględniając ich podgrupy. Rozporządzenie [4] podaje następujące grupy gruntów, wydzielone w oparciu o sposób ich użytkowania na danym terenie, określone zgodnie z ewidencją gruntów i budynków:

- grupa gruntów I - tereny mieszkaniowe, inne tereny zabudowane, zurbanizowane tereny niezabudowane lub w trakcie zabudowy, grunty rolne zabudowane, tereny rekreacyjno-wypoczynkowe (takie jak: tereny ośrodków wypoczynkowych, tereny zabaw dziecięcych, plaże, urządzone parki, skwery, zieleńce (poza pasami ulic), tereny sportowe, tereny spełniające funkcje rozrywkowe, ogrody zoologiczne i botaniczne),

- grupa gruntów II - grunty orne, tereny rodzinnych ogrodów działkowych, sady, łąki trwałe, pastwiska trwałe, grunty pod stawami, grunty pod rowami, tereny rodzinnych ogrodów działkowych, 
- grupa gruntów III - lasy, grunty zadrzewione i zakrzewione, grunty zadrzewione i zakrzewione na użytkach rolnych, nieużytki, tereny rekreacyjno-wypoczynkowe (takie jak: tereny o charakterze zabytkowym, tereny zieleni nieurządzonej niezaliczone do lasów oraz gruntów zadrzewionych i zakrzewionych), użytki ekologiczne, tereny różne, - grupa gruntów IV - tereny przemysłowe, użytki kopalne, tereny komunikacyjne (drogi, tereny kolejowe, inne tereny komunikacyjne, grunty przeznaczone pod budowę dróg publicznych lub linii kolejowych).

Jeżeli dla danego terenu opracowano miejscowy plan zagospodarowania przestrzennego, grupy gruntów wydzielone w oparciu o sposób ich użytkowania na danym terenie określa się zgodnie z jego przeznaczeniem wskazanym w miejscowym planie zagospodarowania przestrzennego w następujący sposób:

- grupa gruntów I - tereny zabudowy mieszkaniowej jednorodzinnej, tereny zabudowy mieszkaniowej wielorodzinnej, tereny zabudowy usługowej, tereny sportu i rekreacji, tereny rozmieszczenia obiektów handlowych o powierzchni sprzedaży powyżej $2000 \mathrm{~m}^{2}$, tereny zabudowy zagrodowej w gospodarstwach rolnych, hodowlanych i ogrodniczych, tereny obsługi produkcji w gospodarstwach rolnych, hodowlanych, ogrodniczych oraz gospodarstwach leśnych i rybackich, tereny zieleni urządzonej (parki, ogrody, zieleń towarzysząca obiektom budowlanym, zieleńce, arboreta, alpinaria), cmentarze,
- grupa gruntów II - tereny rolnicze oraz tereny ogrodów działkowych,

- grupa gruntów III - lasy, grodziska, kurhany, zabytkowe fortyfikacje, tereny zieleni objęte formami ochrony przyrody zgodnie z przepisami o ochronie przyrody,

- grupa gruntów IV - tereny obiektów produkcyjnych, składów i magazynów, obszary i tereny górnicze, tereny dróg publicznych, tereny dróg wewnętrznych, tereny infrastruktury technicznej.

Obszary poddane ochronie na podstawie przepisów Ustawy z dnia 18 lipca 2001 r. - Prawo wodne zalicza się do grupy gruntów I - bez względu na oznaczenie w ewidencji gruntów i budynków lub w miejscowym planie zagospodarowania przestrzennego. Natomiast parki narodowe i rezerwaty przyrody, o których mowa w Ustawie z dnia 16 kwietnia 2004 r. o ochronie przyrody zalicza się do grupy gruntów II - bez względu na oznaczenie w ewidencji gruntów i budynków lub $\mathrm{w}$ miejscowym planie zagospodarowania przestrzennego.

W przypadku grupy gruntów II dla głębokości $0 \div 0,25 \mathrm{~m}$ poniżej poziomu terenu (ppt) określa się podgrupy gruntów wydzielone w oparciu o właściwości gleby.

Dopuszczalne zawartości dla głębokości przekraczającej 0,25 m ppt dla wszystkich grup gruntów określa się z uwzględnieniem wodoprzepuszczalności gleby i ziemi. W tablicy 1 zebrano i porównano dopuszczalne zawartości poszczególnych zanieczyszczeń węglowodorowych określone w obydwu rozporządzeniach.

Tablica 1. Porównanie dopuszczalnych zawartości poszczególnych substancji w glebie i ziemi, określonych w rozporządzeniach $[4,5]$

\begin{tabular}{|c|c|c|}
\hline Parametr & Rozporządzenie [5] & Rozporządzenie [4] \\
\hline Grupy gruntów & trzy & cztery \\
\hline Interwały głębokości & $\begin{array}{l}\text { ilość i rodzaj zależny od grupy gruntów; gru- } \\
\text { pa } A-\text { brak wyszczególnionych, grupa } B-3 \\
\text { interwały }(0 \div 0,3 \mathrm{~m} \mathrm{ppt}, 0,3 \div 15 \mathrm{~m} \mathrm{ppt} \text { oraz }> \\
15 \mathrm{~m} \text { ppt }) \text {, grupa } \mathrm{C}-2 \text { interwały }(0 \div 2 \mathrm{~m} \mathrm{ppt} \\
\text { oraz } 2 \div 15 \mathrm{~m} \text { ppt })\end{array}$ & $\begin{array}{l}\text { ilość niezależna od grupy gruntów; } 2 \text { interwa- } \\
\text { ły }(0 \div 0,25 \mathrm{~m} \text { ppt oraz }>0,25 \mathrm{~m} \mathrm{ppt})\end{array}$ \\
\hline \multicolumn{3}{|c|}{ Dopuszczalne zawartości poszczególnych węglowodorów lub ich sum w warstwie $0 \div 0,25 \mathrm{~m} \mathrm{ppt} \mathrm{[mg/kg} \mathrm{s.m.]}$} \\
\hline Suma węglowodorów $\mathrm{C}_{6}-\mathrm{C}_{12}$ & $\begin{array}{l}\text { Gr. } A-1,0 \\
\text { Gr. } B-1,0 \\
\text { Gr. } C-50,0\end{array}$ & $\begin{array}{l}\text { Gr. I - 1,0 } \\
\text { Gr. II - } 1,0 \\
\text { Gr. III - 50,0 } \\
\text { Gr. IV - 500 }\end{array}$ \\
\hline Suma węglowodorów $\mathrm{C}_{12}-\mathrm{C}_{35}$ & $\begin{array}{l}\text { Gr. } A-30,0 \\
\text { Gr. } B-50,0 \\
\text { Gr. } C-1000\end{array}$ & $\begin{array}{l}\text { Gr. I - 30,0 } \\
\text { Gr. II - 50,0 } \\
\text { Gr. III - 300 } \\
\text { Gr. IV }-3000\end{array}$ \\
\hline Benzen & $\begin{array}{l}\text { Gr. A }-0,05 \\
\text { Gr. B }-0,1 \\
\text { Gr. C }-100\end{array}$ & $\begin{array}{l}\text { Gr. I - 0,1 } \\
\text { Gr. II - } 0,1 \\
\text { Gr. III - } 10 \\
\text { Gr. IV - } 100\end{array}$ \\
\hline
\end{tabular}


cd. Tablica 1

\begin{tabular}{|c|c|c|}
\hline Parametr & Rozporządzenie [5] & Rozporządzenie [4] \\
\hline Etylobenzen & $\begin{array}{l}\text { Gr. } A-0,05 \\
\text { Gr. } B-0,1 \\
\text { Gr. } C-200\end{array}$ & $\begin{array}{l}\text { Gr. I - 0,1 } \\
\text { Gr. II - 0,1 } \\
\text { Gr. III - } 10 \\
\text { Gr. IV }-100\end{array}$ \\
\hline Toluen & $\begin{array}{l}\text { Gr. } A-0,05 \\
\text { Gr. } B-0,1 \\
\text { Gr. } C-200\end{array}$ & $\begin{array}{l}\text { Gr. I - 0,1 } \\
\text { Gr. II - 0,1 } \\
\text { Gr. III - } 10 \\
\text { Gr. IV }-100\end{array}$ \\
\hline Ksyleny & $\begin{array}{l}\text { Gr. } A-0,05 \\
\text { Gr. } B-0,1 \\
\text { Gr. } C-100\end{array}$ & $\begin{array}{l}\text { Gr. I - 0,1 } \\
\text { Gr. II - 0,1 } \\
\text { Gr. III - } 10 \\
\text { Gr. IV }-100\end{array}$ \\
\hline Styren & $\begin{array}{l}\text { Gr. } A-0,1 \\
\text { Gr. } B-0,1 \\
\text { Gr. C }-60\end{array}$ & $\begin{array}{l}\text { Gr. I }-0,1 \\
\text { Gr. II }-0,1 \\
\text { Gr. III }-6,0 \\
\text { Gr. IV }-60\end{array}$ \\
\hline Suma BTEX & $\begin{array}{l}\text { Gr. } A-0,1 \\
\text { Gr. B }-0,1 \\
\text { Gr. C }-200\end{array}$ & $\begin{array}{l}\text { Gr. I - brak limitu } \\
\text { Gr. II - brak limitu } \\
\text { Gr. III - brak limitu } \\
\text { Gr. IV - brak limitu }\end{array}$ \\
\hline Naftalen & $\begin{array}{l}\text { Gr. } A-0,1 \\
\text { Gr. } B-0,1 \\
\text { Gr. } C-50,0\end{array}$ & $\begin{array}{l}\text { Gr. I }-0,1 \\
\text { Gr. II }-0,1 \\
\text { Gr. III }-1,0 \\
\text { Gr. IV }-20,0\end{array}$ \\
\hline Antracen & $\begin{array}{l}\text { Gr. } A-0,1 \\
\text { Gr. } B-0,1 \\
\text { Gr. } C-50,0\end{array}$ & $\begin{array}{l}\text { Gr. I }-0,2 \\
\text { Gr. II }-0,2 \\
\text { Gr. III }-1,0 \\
\text { Gr. IV }-20,0\end{array}$ \\
\hline Chryzen & $\begin{array}{l}\text { Gr. } A-0,1 \\
\text { Gr. } B-0,1 \\
\text { Gr. } C-50,0\end{array}$ & $\begin{array}{l}\text { Gr. I }-0,2 \\
\text { Gr. II }-0,2 \\
\text { Gr. III }-1,0 \\
\text { Gr. IV }-20,0\end{array}$ \\
\hline Benzo(a)antracen & $\begin{array}{l}\text { Gr. } A-0,1 \\
\text { Gr. } B-0,1 \\
\text { Gr. } C-50,0\end{array}$ & $\begin{array}{l}\text { Gr. I - 0,1 } \\
\text { Gr. II - } 0,1 \\
\text { Gr. III - } 1,0 \\
\text { Gr. IV }-20,0\end{array}$ \\
\hline Dibenzo(a,h)antracen & $\begin{array}{l}\text { Gr. A - brak limitu } \\
\text { Gr. B - brak limitu } \\
\text { Gr. } C \text { - brak limitu }\end{array}$ & $\begin{array}{l}\text { Gr. I }-0,1 \\
\text { Gr. II }-0,1 \\
\text { Gr. III }-1,0 \\
\text { Gr. IV }-20,0\end{array}$ \\
\hline Benzo(a)piren & $\begin{array}{l}\text { Gr. } A-0,02 \\
\text { Gr. } B-0,03 \\
\text { Gr. } C-50,0\end{array}$ & $\begin{array}{l}\text { Gr. I }-0,1 \\
\text { Gr. II }-0,1 \\
\text { Gr. III }-1,0 \\
\text { Gr. IV }-20,0\end{array}$ \\
\hline Benzo(b)fluoranten & $\begin{array}{l}\text { Gr. } A \text { - brak limitu } \\
\text { Gr. } B \text { - brak limitu } \\
\text { Gr. } C \text { - brak limitu }\end{array}$ & $\begin{array}{l}\text { Gr. I }-0,1 \\
\text { Gr. II }-0,1 \\
\text { Gr. III }-1,0 \\
\text { Gr. IV }-20,0\end{array}$ \\
\hline Benzo(k)fluoranten & $\begin{array}{l}\text { Gr. A - brak limitu } \\
\text { Gr. B - brak limitu } \\
\text { Gr. } C \text { - brak limitu }\end{array}$ & $\begin{array}{l}\text { Gr. I }-0,1 \\
\text { Gr. II }-0,1 \\
\text { Gr. III }-1,0 \\
\text { Gr. IV }-20,0\end{array}$ \\
\hline Benzo(g,h,i)perylen & $\begin{array}{c}\text { Gr. A - 0,1 } \\
\text { Gr. B - 0,1 } \\
\text { Gr. C }-50,0\end{array}$ & $\begin{array}{c}\text { Gr. I - 0,2 } \\
\text { Gr. II - 0,2 } \\
\text { Gr. III - 1,0 } \\
\text { Gr. IV - 20,0 }\end{array}$ \\
\hline
\end{tabular}


cd. Tablica 1

\begin{tabular}{|c|c|c|}
\hline Parametr & Rozporządzenie [5] & Rozporządzenie [4] \\
\hline Indeno(1,2,3-c,d)piren & $\begin{array}{l}\text { Gr. A - brak limitu } \\
\text { Gr. B - brak limitu } \\
\text { Gr. } C \text { - brak limitu }\end{array}$ & $\begin{array}{l}\text { Gr. I }-0,2 \\
\text { Gr. II }-0,2 \\
\text { Gr. III - 1,0 } \\
\text { Gr. IV }-20,0\end{array}$ \\
\hline Fenantren & $\begin{array}{l}\text { Gr. } A-0,1 \\
\text { Gr. B }-0,1 \\
\text { Gr. } C-50,0\end{array}$ & $\begin{array}{l}\text { Gr. I - brak limitu } \\
\text { Gr. II - brak limitu } \\
\text { Gr. III - brak limitu } \\
\text { Gr. IV - brak limitu }\end{array}$ \\
\hline Fluoranten & $\begin{array}{l}\text { Gr. } A-0,1 \\
\text { Gr. } B-0,1 \\
\text { Gr. } C-50,0\end{array}$ & $\begin{array}{l}\text { Gr. I - brak limitu } \\
\text { Gr. II - brak limitu } \\
\text { Gr. III - brak limitu } \\
\text { Gr. IV - brak limitu }\end{array}$ \\
\hline Benzo(a)fluoranten & $\begin{array}{l}\text { Gr. } A-0,1 \\
\text { Gr. } B-0,1 \\
\text { Gr. } C-50,0\end{array}$ & $\begin{array}{l}\text { Gr. I - brak limitu } \\
\text { Gr. II - brak limitu } \\
\text { Gr. III - brak limitu } \\
\text { Gr. IV - brak limitu }\end{array}$ \\
\hline Suma WWA & $\begin{array}{l}\text { Gr. } A-1,0 \\
\text { Gr. } B-1,0 \\
\text { Gr. } C-250\end{array}$ & $\begin{array}{l}\text { Gr. I - brak limitu } \\
\text { Gr. II - brak limitu } \\
\text { Gr. III - brak limitu } \\
\text { Gr. IV - brak limitu }\end{array}$ \\
\hline \multicolumn{3}{|c|}{ Dopuszczalne zawartości poszczególnych węglowodorów lub ich sum w warstwie > 0,25 m ppt [mg/kg s.m.] } \\
\hline Suma węglowodorów $\mathrm{C}_{6}-\mathrm{C}_{12}$ & $\begin{array}{l}\text { Gr. } A-1,0 \\
\text { Gr. } B-5,0 \div 750 \\
\text { Gr. } C-50,0 \div 750\end{array}$ & $\begin{array}{l}\text { Gr. I }-50 \div 500 \\
\text { Gr. II }-50 \div 500 \\
\text { Gr. III }-50 \div 500 \\
\text { Gr. IV }-50 \div 750\end{array}$ \\
\hline Suma węglowodorów $\mathrm{C}_{12}-\mathrm{C}_{35}$ & $\begin{array}{l}\text { Gr. } A-30 \\
\text { Gr. } B-200 \div 3000 \\
\text { Gr. } C-1000 \div 3000\end{array}$ & $\begin{array}{l}\text { Gr. I }-1000 \div 3000 \\
\text { Gr. II }-1000 \div 3000 \\
\text { Gr. III }-1000 \div 3000 \\
\text { Gr. IV }-1000 \div 3000\end{array}$ \\
\hline Benzen & $\begin{array}{l}\text { Gr. } A-0,05 \\
\text { Gr. } B-0,2 \div 50,0 \\
\text { Gr. } C-3,0 \div 150\end{array}$ & $\begin{array}{l}\text { Gr. I }-1,0 \div 25,0 \\
\text { Gr. II }-1,0 \div 25,0 \\
\text { Gr. III }-1,0 \div 25,0 \\
\text { Gr. IV }-3,0 \div 150\end{array}$ \\
\hline Etylobenzen & $\begin{array}{l}\text { Gr. } A-0,05 \\
\text { Gr. } B-1,0 \div 150 \\
\text { Gr. } C-10 \div 250\end{array}$ & $\begin{array}{l}\text { Gr. I }-1,0 \div 75,0 \\
\text { Gr. II }-1,0 \div 75,0 \\
\text { Gr. III }-1,0 \div 75,0 \\
\text { Gr. IV }-10 \div 250\end{array}$ \\
\hline Toluen & $\begin{array}{l}\text { Gr. } A-0,05 \\
\text { Gr. } B-1,0 \div 150 \\
\text { Gr. } C-5,0 \div 230\end{array}$ & $\begin{array}{l}\text { Gr. I }-1,0 \div 75,0 \\
\text { Gr. II }-1,0 \div 75,0 \\
\text { Gr. III }-1,0 \div 75,0 \\
\text { Gr. IV }-5,0 \div 230\end{array}$ \\
\hline Ksyleny & $\begin{array}{l}\text { Gr. } A-0,05 \\
\text { Gr. } B-1,0 \div 75,0 \\
\text { Gr. } C-5,0 \div 150\end{array}$ & $\begin{array}{l}\text { Gr. I }-1,0 \div 35,0 \\
\text { Gr. II }-1,0 \div 35,0 \\
\text { Gr. III }-1,0 \div 35,0 \\
\text { Gr. IV }-5,0 \div 150\end{array}$ \\
\hline Styren & $\begin{array}{l}\text { Gr. } A-0,1 \\
\text { Gr. } B-1,0 \div 100 \\
\text { Gr. } C-2,0 \div 100\end{array}$ & $\begin{array}{l}\text { Gr. I }-1,0 \div 5,0 \\
\text { Gr. II }-1,0 \div 5,0 \\
\text { Gr. III }-1,0 \div 5,0 \\
\text { Gr. IV }-2,0 \div 100\end{array}$ \\
\hline Suma BTEX & $\begin{array}{l}\text { Gr. } A-0,1 \\
\text { Gr. } B-1,0 \div 150 \\
\text { Gr. } C-10,0 \div 250\end{array}$ & $\begin{array}{l}\text { Gr. I - brak limitu } \\
\text { Gr. II - brak limitu } \\
\text { Gr. III - brak limitu } \\
\text { Gr. IV - brak limitu }\end{array}$ \\
\hline
\end{tabular}


cd. Tablica 1

\begin{tabular}{|c|c|c|}
\hline Parametr & Rozporządzenie [5] & Rozporządzenie [4] \\
\hline Naftalen & $\begin{array}{l}\text { Gr. } A-0,1 \\
\text { Gr. } B-5,0 \div 40,0 \\
\text { Gr. } C-10,0 \div 40,0\end{array}$ & $\begin{array}{l}\text { Gr. I }-5,0 \div 20,0 \\
\text { Gr. II }-5,0 \div 20,0 \\
\text { Gr. III }-5,0 \div 20,0 \\
\text { Gr. IV }-10,0 \div 40,0\end{array}$ \\
\hline Antracen & $\begin{array}{l}\text { Gr. } A-0,1 \\
\text { Gr. } B-5,0 \div 40,0 \\
\text { Gr. } C-10,0 \div 40,0\end{array}$ & $\begin{array}{l}\text { Gr. I }-5,0 \div 20,0 \\
\text { Gr. II }-5,0 \div 20,0 \\
\text { Gr. III }-5,0 \div 20,0 \\
\text { Gr. IV }-10,0 \div 40,0\end{array}$ \\
\hline Chryzen & $\begin{array}{c}\text { Gr. } A-0,1 \\
\text { Gr. } B-5,0 \div 40,0 \\
\text { Gr. } C-10,0 \div 40,0\end{array}$ & $\begin{array}{c}\text { Gr. I }-5,0 \div 20,0 \\
\text { Gr. II }-5,0 \div 20,0 \\
\text { Gr. III }-5,0 \div 20,0 \\
\text { Gr. IV }-10,0 \div 40,0\end{array}$ \\
\hline Benzo(a)antracen & $\begin{array}{l}\text { Gr. } A-0,1 \\
\text { Gr. } B-5,0 \div 40,0 \\
\text { Gr. } C-10,0 \div 40,0\end{array}$ & $\begin{array}{l}\text { Gr. I }-5,0 \div 20,0 \\
\text { Gr. II }-5,0 \div 20,0 \\
\text { Gr. III }-5,0 \div 20,0 \\
\text { Gr. IV }-10,0 \div 40,0\end{array}$ \\
\hline Dibenzo(a,h)antracen & $\begin{array}{l}\text { Gr. A - brak limitu } \\
\text { Gr. B - brak limitu } \\
\text { Gr. C - brak limitu }\end{array}$ & $\begin{array}{l}\text { Gr. I - 5,0 } 20,0 \\
\text { Gr. II }-5,0 \div 20,0 \\
\text { Gr. III }-5,0 \div 20,0 \\
\text { Gr. IV }-5,0 \div 20,0\end{array}$ \\
\hline Benzo(a)piren & $\begin{array}{l}\text { Gr. } A-0,02 \\
\text { Gr. } B-5,0 \div 40,0 \\
\text { Gr. } C-5,0 \div 40,0\end{array}$ & $\begin{array}{l}\text { Gr. I }-5,0 \div 20,0 \\
\text { Gr. II }-5,0 \div 20,0 \\
\text { Gr. III }-5,0 \div 20,0 \\
\text { Gr. IV }-5,0 \div 40,0\end{array}$ \\
\hline Benzo(b)fluoranten & $\begin{array}{l}\text { Gr. A - brak limitu } \\
\text { Gr. B - brak limitu } \\
\text { Gr. C - brak limitu }\end{array}$ & $\begin{array}{l}\text { Gr. I }-5,0 \div 20,0 \\
\text { Gr. II }-5,0 \div 20,0 \\
\text { Gr. III }-5,0 \div 20,0 \\
\text { Gr. IV }-5,0 \div 20,0\end{array}$ \\
\hline Benzo(k)fluoranten & $\begin{array}{l}\text { Gr. A - brak limitu } \\
\text { Gr. B - brak limitu } \\
\text { Gr. C - brak limitu }\end{array}$ & $\begin{array}{l}\text { Gr. I }-5,0 \div 20,0 \\
\text { Gr. II }-5,0 \div 20,0 \\
\text { Gr. III }-5,0 \div 20,0 \\
\text { Gr. IV }-5,0 \div 20,0\end{array}$ \\
\hline Benzo(g,h,i)perylen & $\begin{array}{l}\text { Gr. } A-0,1 \\
\text { Gr. } B-5,0 \div 40,0 \\
\text { Gr. } C-5,0 \div 100\end{array}$ & $\begin{array}{l}\text { Gr. I }-5,0 \div 20,0 \\
\text { Gr. II }-5,0 \div 20,0 \\
\text { Gr. III }-5,0 \div 20,0 \\
\text { Gr. IV }-5,0 \div 100\end{array}$ \\
\hline Indeno(1,2,3-c,d)piren & $\begin{array}{l}\text { Gr. A - brak limitu } \\
\text { Gr. B - brak limitu } \\
\text { Gr. C - brak limitu }\end{array}$ & $\begin{array}{l}\text { Gr. I }-5,0 \div 20,0 \\
\text { Gr. II }-5,0 \div 20,0 \\
\text { Gr. III }-5,0 \div 20,0 \\
\text { Gr. IV }-5,0 \div 20,0\end{array}$ \\
\hline Fenantren & $\begin{array}{l}\text { Gr. } A-0,1 \\
\text { Gr. } B-5,0 \div 40,0 \\
\text { Gr. } C-10,0 \div 40,0\end{array}$ & $\begin{array}{l}\text { Gr. I - brak limitu } \\
\text { Gr. II - brak limitu } \\
\text { Gr. III - brak limitu } \\
\text { Gr. IV - brak limitu }\end{array}$ \\
\hline Fluoranten & $\begin{array}{l}\text { Gr. } A-0,1 \\
\text { Gr. } B-5,0 \div 40,0 \\
\text { Gr. } C-10,0 \div 40,0\end{array}$ & $\begin{array}{l}\text { Gr. I - brak limitu } \\
\text { Gr. II - brak limitu } \\
\text { Gr. III - brak limitu } \\
\text { Gr. IV - brak limitu }\end{array}$ \\
\hline Benzo(a)fluoranten & $\begin{array}{l}\text { Gr. } A-0,1 \\
\text { Gr. } B-5,0 \div 40,0 \\
\text { Gr. } C-5,0 \div 40,0\end{array}$ & $\begin{array}{l}\text { Gr. I - brak limitu } \\
\text { Gr. II - brak limitu } \\
\text { Gr. III - brak limitu } \\
\text { Gr. IV - brak limitu }\end{array}$ \\
\hline Suma WWA & $\begin{array}{l}\text { Gr. } A-1,0 \\
\text { Gr. } B-20,0 \div 200 \\
\text { Gr. } C-20,0 \div 200\end{array}$ & $\begin{array}{l}\text { Gr. I - brak limitu } \\
\text { Gr. II - brak limitu } \\
\text { Gr. III - brak limitu } \\
\text { Gr. IV - brak limitu }\end{array}$ \\
\hline
\end{tabular}


Analiza danych zawartych w tablicy 1 pokazuje, że nowe rozporządzenie [4] nie wymaga oznaczania w badanych próbkach sumy jedno- i wielopierścieniowych węglowodorów aromatycznych, a więc sumy BTEX i WWA, oraz wprowadza zmiany w zakresie określania pojedynczych węglowodorów z grupy WWA.

Rozporządzenie [4] identyfikuje również tereny zanieczyszczone w pięciu etapach:

- etap pierwszy - określenie działalności mogącej być przyczyną zanieczyszczenia na danym terenie, obecnie lub w przeszłości,

- etap drugi - ustalenie listy substancji powodujących ryzyko, których wystapienie w glebie lub w ziemi jest spodziewane na danym terenie,

- etap trzeci - zebranie oraz analiza dostępnych i aktualnych źródeł informacji istotnych dla oceny zagrożenia zanieczyszczeniem gleby lub ziemi na danym terenie oraz dostępnych i aktualnych badań zanieczyszczenia gleby i ziemi substancjami powodującymi ryzyko z listy ustalonej w etapie drugim,

- etap czwarty - zebranie informacji koniecznych do wykonania badań wstępnych oraz przeprowadzenie tych badań,

- etap piąty - wykonanie badań szczegółowych.

Nowością w stosunku do obowiązującego wcześniej dokumentu [5] jest załącznik nr 2 rozporządzenia [4], w którym zostały określone rodzaje działalności mogących z dużym prawdopodobieństwem powodować historyczne zanieczyszczenie powierzchni ziemi, w tym rodzaje działalności obejmujące eksploatację wybranych typów instalacji mogących wywoływać znaczne zanieczyszczenie poszczególnych elementów przyrodniczych albo środowiska jako całości, rodzaje działalności stanowiące wybrane typy przedsięwzięć mogących znacząco oddziaływać na środowisko oraz inne rodzaje aktywności. Załącznik nr 2 podaje również przykładowe dla wskazanych działalności zanieczyszczenia.

W załączniku tym wśród działalności stanowiących wybrane rodzaje przedsięwzięć mogących znacząco oddziaływać na środowisko wymienione zostały m.in.:

- poszukiwanie lub rozpoznawanie złóż kopalin,

- wydobywanie ze złoża gazu, ropy naftowej oraz jej naturalnych pochodnych lub ich przerób, w ilości większej niż $500000 \mathrm{~m}^{3}$ na dobę w przypadku gazu lub większej niż 500 ton na dobę w przypadku ropy naftowej i jej naturalnych pochodnych,

- instalacje do przesyłu ropy naftowej, produktów naftowych, substancji lub mieszanin, w rozumieniu Ustawy z dnia 25 lutego 2011 r. o substancjach chemicznych i ich mieszaninach, niebedacych produktami spożywczy$m i$ (Dz. U. z 2011 r. nr 63, poz. 322) [7], w tym gazu, o średnicy zewnętrznej nie mniejszej niż $800 \mathrm{~mm}$ i dłu- gości nie mniejszej niż $40 \mathrm{~km}$, wraz z towarzyszącymi tłoczniami lub stacjami redukcyjnymi,

- instalacje do magazynowania ropy naftowej, produktów naftowych, substancji lub mieszanin, w rozumieniu przepisów ustawy [7], o łącznej pojemności nie mniejszej niż 200000 ton, wraz z urządzeniami do przeładunku,

- instalacje do dystrybucji ropy naftowej, produktów naftowych, substancji lub mieszanin, w rozumieniu przepisów ustawy [7], z wyłączeniem stacji paliw gazu płynnego. Dla tego typu instalacji wśród przykładowych zanieczyszczeń wymienione zostały głównie węglowodory, w tym:

- benzyny i oleje (suma węglowodorów $\mathrm{C}_{6}-\mathrm{C}_{12}$, składników frakcji benzyn oraz suma węglowodorów $\mathrm{C}_{12}-\mathrm{C}_{35}$, składników frakcji oleju),

- węglowodory aromatyczne (benzen, etylobenzen, toluen, ksyleny, styren),

- wielopierścieniowe węglowodory aromatyczne (naftalen, antracen, chryzen, benzo(a)antrancen, $\operatorname{dibenzo}(\mathrm{a}, \mathrm{h})$ antracen, benzo(a)piren, benzo(b)fluaranten, benzo(k)fluaranten, benzo(ghi)perylen oraz indeno(1,2,3-c,d)piren). Wprowadzenie załącznika $\mathrm{nr} 2$ do rozporządzenia [4] wynika z realizacji zapisów art. 101a. pkt 5.4 Ustawy z dnia 27 kwietnia 2001 r. - Prawo ochrony środowiska (Dz. U. z 2001 r. nr 62, poz. 627, z późn. zm.) [6]. Ustawa [6] definiuje historyczne zanieczyszczenie powierzchni ziemi jako zanieczyszczenie, które zaistniało przed dniem 30 kwietnia 2007 r. lub wynika $\mathrm{z}$ działalności, która została zakończona przed dniem 30 kwietnia 2007 r. Zgodnie z definicją zawartą w ustawie [6] pod pojęciem historycznego zanieczyszczenia powierzchni ziemi rozumie się także szkodę w powierzchni ziemi (skażenie gleby lub ziemi, w tym w szczególności zanieczyszczenie mogące stanowić zagrożenie dla zdrowia ludzi) spowodowaną przez emisję lub zdarzenie, od którego upłynęło więcej niż 30 lat.

Należy jeszcze dodać, że rozporządzenie [4] zawiera załącznik nr 3, w którym ujęto:

- metodyki referencyjne określania schematu lokalizacji punktów pobierania próbek oraz rodzajów, głębokości i sposobu pobierania próbek do badań, a także ich transportu i przechowywania,

- metodyki referencyjne przygotowania próbek do badań właściwości gleby i ziemi oraz pomiarów zawartości substancji powodujących ryzyko w glebie lub w ziemi,

- metodyki referencyjne badania właściwości gleby lub ziemi,

- metodyki referencyjne pomiarów zawartości substancji powodujących ryzyko w glebie lub w ziemi.

Rekomendowane przez rozporządzenie [4] metodyki referencyjne w pomiarach i badaniach zanieczyszczeń węglowodorowych w różnych elementach środowiska zestawiono w tablicy 2. 
Tablica 2. Metodyki referencyjne dla pomiarów zawartości substancji powodujących ryzyko w glebie lub w ziemi [4]

\begin{tabular}{|c|c|c|}
\hline $\begin{array}{c}\text { Substancja } \\
\text { powodująca ryzyko }\end{array}$ & Metoda instrumentalna & Metodyka referencyjna \\
\hline \multicolumn{3}{|r|}{ BENZYNY I OLEJE } \\
\hline \multirow{2}{*}{$\begin{array}{l}\text { Suma węglowodorów } \\
\mathrm{C}_{6}-\mathrm{C}_{12} \text {, składników } \\
\text { frakcji benzyn }\end{array}$} & $\begin{array}{l}\text { Chromatografia gazowa GC } \\
\text { z detektorem FID albo MS }\end{array}$ & $\begin{array}{l}\text { Procedura badawcza na podstawie PN EN ISO } 16703 \text { Jakość gleby-Ozna- } \\
\text { czanie zawartości węlowodorów w zakresie od } C_{10} \text { do } C_{40} \text { metoda chroma- } \\
\text { tografii gazowej }\end{array}$ \\
\hline & $\begin{array}{l}\text { Chromatografia gazowa GC } \\
\text { z detektorem FID albo MS } \\
\text { z techniką analizy fazy nad- } \\
\text { powierzchniowej }\end{array}$ & $\begin{array}{l}\text { Procedura badawcza na podstawie PN EN ISO } 22155 \text { Jakość gleby - ozna- } \\
\text { czanie ilościowe lotnych węglowodorów aromatycznych, lotnych węglowo- } \\
\text { dorów halogenowych oraz wybranych eterów z zastosowaniem chromato- } \\
\text { grafii gazowej - Metoda statycznej analizy fazy nadpowierzchniowej }\end{array}$ \\
\hline $\begin{array}{l}\text { Suma węglowodorów } \\
\mathrm{C}_{12}-\mathrm{C}_{35} \text {, składników } \\
\text { frakcji oleju }\end{array}$ & $\begin{array}{l}\text { Chromatografia gazowa GC } \\
\text { z detektorem FID albo MS }\end{array}$ & $\begin{array}{l}\text { Procedura badawcza na podstawie PN ISO } 16703 \text { Jakość gleby - Oznacza- } \\
\text { nie zawartości węglowodorów w zakresie od } C_{10} \text { do } C_{40} \text { metoda chromato- } \\
\text { grafi gazowej }\end{array}$ \\
\hline \multicolumn{3}{|c|}{ JEDNOPIERŚCIENIOWE WĘGLOWODORY AROMATYCZNE } \\
\hline Benzen & \multirow{5}{*}{$\begin{array}{l}\text { Chromatografia gazowa GC } \\
\text { z detektorem FID albo ECD } \\
\text { lub MS }\end{array}$} & \multirow{5}{*}{$\begin{array}{l}\text { Procedura badawcza na podstawie PN-EN ISO } 15009 \text { Jakość gleby - Ozna- } \\
\text { czanie zawartości lotnych węglowodorów aromatycznych, naftalenu oraz } \\
\text { lotnych węglowodorów halogenowanych metoda chromatografi gazo- } \\
\text { wej-Metoda usuwania i wychwytu z desorpcja termiczna albo PN-EN ISO } \\
22155 \text { Jakość gleby - Oznaczanie ilościowe lotnych węglowodorów aroma- } \\
\text { tycznych, lotnych węglowodorów halogenowanych oraz wybranych eterów } \\
\text { z zastosowaniem chromatografi gazowej - Metoda statycznej analizy fazy } \\
\text { nadpowierzchniowej }\end{array}$} \\
\hline Etylobenzen & & \\
\hline Toluen & & \\
\hline Ksyleny & & \\
\hline Styren & & \\
\hline \multicolumn{3}{|c|}{ WIELOPIERŚCIENIOWE WĘGLOWODORY AROMATYCZNE } \\
\hline \multirow{2}{*}{$\begin{array}{l}\text { Naftalen } \\
\text { Antracen } \\
\text { Chryzen } \\
\text { Benzo(a)antracen } \\
\text { Dibenzo(a,h)antracen } \\
\text { Benzo(a)piren } \\
\text { Benzo(b)fluoranten } \\
\text { Benzo(k)fluoranten } \\
\text { Benzo(ghi)perylen } \\
\text { Indeno(1,2,3-c,d)piren }\end{array}$} & $\begin{array}{l}\text { Chromatografia cieczowa } \\
\text { HPLC z detektorem UV } \\
\text { albo FL lub chromatografia } \\
\text { cieczowa UPLC z detekto- } \\
\text { rem UV albo FL }\end{array}$ & $\begin{array}{l}\text { Procedura badawcza na podstawie PN ISO } 13877 \text { Jakość gleby - Oznacza- } \\
\text { nie wielopierścieniowych węglowodorów aromatycznych-Metoda z zasto- } \\
\text { sowaniem wysokosprawnej chromatografi cieczowej }\end{array}$ \\
\hline & $\begin{array}{l}\text { Chromatografia gazowa } \\
\text { z detekcją za pomocą spek- } \\
\text { trometrii mas (GCMS) }\end{array}$ & $\begin{array}{l}\text { Procedura badawcza na podstawie PN ISO } 18287 \text { Jakość gleby - Oznacza- } \\
\text { nie zawartości wielopierścieniowych węglowodorów aromatycznych (PAH) } \\
\text { - Metoda chromatografii gazowej z detekcja za pomoca spektrometrii mas } \\
\text { (GC-MS) albo na podstawie PN-EN ISO } 15009 \text { Jakość gleby - Oznaczanie } \\
\text { zawartości lotnych weglowodorów aromatycznych, naftalenu oraz lotnych } \\
\text { węglowodorów halogenowanych metoda chromatografii gazowej- Metoda } \\
\text { usuwania i wychwytu z desorpcja termicznq }\end{array}$ \\
\hline
\end{tabular}

Należy dodać, że przeprowadzenie oceny zgodnie z obowiązującym aktualnie rozporządzeniem, ale na podstawie wcześniej wykonanych badań, jest zgodne z zapisem § 14 rozporządzenia [4]. Zapisy tego paragrafu dopuszczają wykorzystanie w postępowaniach wszczętych i niezakończonych przed dniem wejścia w życie niniejszego dokumentu wyników badań zanieczyszczenia gleby i ziemi wykonanych przed dniem uzyskania ważności tego rozporządzenia, zgodnie z dotych- czasowymi przepisami przez laboratorium, o którym mowa w art. 147a ust. 1 pkt 1 lub ust. 1a Ustawy z dnia 27 kwietnia 2001 r. - Prawo ochrony środowiska. Przy czym wyniki pomiarów przeprowadzonych w celu określenia zawartości substancji powodujących ryzyko w pobranych próbkach porównuje się z dopuszczalnymi zawartościami, o których mowa w $\S 3$ ust. 1 niniejszego dokumentu. Takie postępowanie jest możliwe w terminie roku od dnia wejścia w życie rozporządzenia [4].

\section{Podsumowanie}

Środowisko glebowe to naturalny magazyn wielu substancji i związków chemicznych, z których część jest pochodzenia naturalnego. Niestety na stan środowiska glebowego, w tym jego skład chemiczny, duży wpływ mają też czynniki związane z działalnością człowieka. Z tego właśnie względu pro- wadzi się badania oraz monitoring stanu środowiska, podczas których oznacza się zawartości substancji szkodliwych, w tym węglowodorów. W chwili obecnej dopuszczalne zawartości w glebie i ziemi poszczególnych grup węglowodorów oraz pojedynczych związków należących do węglowodorów określa 
rozporządzenie [4]. Wartości dopuszczalnych stężeń węglowodorów określone w tym dokumencie są zróżnicowane w szerokim zakresie (od 0,1 do $3000 \mathrm{mg} / \mathrm{kg}$ s.m.), w zależności od rodzaju oznaczanej substancji. Natomiast podstawową meto- dyką referencyjną przy określaniu węglowodorów alifatycznych jest chromatografia gazowa (GC), a w przypadku oznaczania wielopierścieniowych węglowodorów aromatycznych (WWA) wysokosprawna chromatografia cieczowa (HPLC).

Prosimy cytować jako: Nafta-Gaz 2017, nr 5, s. 350-359, DOI: 10.18668/NG.2017.05.07

Artykuł nadesłano do Redakcji 8.12.2016 r. Zatwierdzono do druku 7.03.2017 r.

Artykuł powstał na podstawie pracy statutowej pt.: Weryfikacja przydatności wybranych metod analitycznych stosowanych $w$ ocenie zanieczyszczeń środowiska węglowodorami - praca INiG - PIB na zlecenie MNiSW; nr zlecenia: 0061/GE/16, nr archiwalny: DK-4100-61/16.

\section{Literatura}

[1] Kluk D., Steliga T.: Ocena zmian toksyczności gleby skażonej niklem i substancjami ropopochodnymi w procesach fitoremediacji. Nafta-Gaz 2016, nr 4, s. 230-241, DOI: 10.18668/ NG.2016.04.02.

[2] Król A., Kukulska-Zając E., Macuda J.: Metody monitoringu i remediacji gruntów zanieczyszczonych rtęcia na terenach przemystowych. Nafta-Gaz 2016, nr 8, s. 626-632, DOI: 10.18668/NG.2016.08.06.

\section{Akty prawne i normatywne}

[3] Dyrektywa Parlamentu Europejskiego i Rady 2010/75/UE $z$ dnia 24 listopada 2010 r. w sprawie emisji przemysłowych (zintegrowane zapobieganie zanieczyszczeniom i ich kontrola) (Dz. U. UE L 334 z 17 grudnia 2010 r., z późn. zm.).

[4] Rozporządzenie Ministra Środowiska z dnia 1 września 2016 r. w sprawie sposobu prowadzenia oceny zanieczyszczenia powierzchni ziemi (Dz. U. z 2016 r. nr 0, poz. 1395).

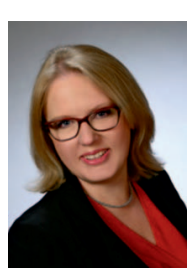

Mgr Anna KRÓL

Starszy specjalista badawczo-techniczny w Zakładzie Ochrony Srodowiska.

Instytut Nafty i Gazu - Państwowy Instytut Badawczy

ul. Lubicz 25 A

31-503 Kraków

E-mail: anna.krol@inig.pl
[5] Rozporzadzenie Ministra Środowiska z dnia 9 września 2002 r. w sprawie standardów jakości gleby oraz standardów jakości ziemi (Dz. U. z 2002 r. nr 165, poz. 1359).

[6] Ustawa z dnia 27 kwietnia 2001 r. Prawo ochrony środowiska (Dz. U. z 2001 r. nr 62, poz. 627, z późn. zm.).

[7] Ustawa z dnia 25 lutego 2011 r. o substancjach chemicznych $i$ ich mieszaninach, niebędacych produktami spożywczymi (Dz. U. z 2011 r. nr 63, poz. 322).

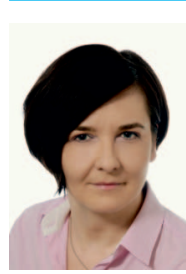

Dr Ewa KUKULSKA-ZAJĄC

Adiunkt; kierownik Zakładu Ochrony Środowiska. Instytut Nafty i Gazu - Państwowy Instytut Badawczy ul. Lubicz 25 A

31-503 Kraków

E-mail: kukulska@inig.pl

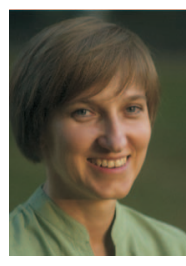

Mgr inż. Marta DOBRZAŃSKA

Główny specjalista inżynieryjno-techniczny

w Zakładzie Ochrony Środowiska.

Instytut Nafty i Gazu - Państwowy Instytut Badawczy ul. Lubicz 25 A

31-503 Kraków

E-mail: marta.dobrzanska@inig.pl 